\title{
The Role of Fetal Hemoglobin in Maternal Blood in Determining the Severity of Pre-Eclampsia
}

\author{
FATMA A. ABDALLA ALI, M.Sc.*; ASHRAF E. GHARIEB, M.D.** and NAREMAN M. EL-HAMAMY, M.D.** \\ The Departments of Emergency Medicine \& Traumatology* and Gynecology \& Obstetrics**, Faculty of Medicine, \\ Tanta University, Tanta, Egypt
}

\begin{abstract}
Background: Preeclampsia is a disorder of widespread vascular endothelial malfunction and vasospasm that occurs after 20 weeks of gestation. At this time, preeclampsia still lacks early means of diagnosis and markers that determine the severity of the condition. Extracellular fetal hemoglobin is involved in the pathogenesis of preeclampsia and its concentration in the maternal blood can be used to determine the severity of preeclampsia.

Patients and Methods: The current work is a retrospective randomized study that was conducted on 60 pregnant women. Patients were classified into two groups. Group I (study group) included 40 patients diagnosed as preeclampsia and subdivided into group IA (included 20 patients diagnosed as mild preeclampsia) and group IB (included 20 patients diagnosed as severe preeclampsia). Group II (control group) included 20 healthy pregnant women with uncomplicated pregnancy.
\end{abstract}

Results: The study revealed as regard socio demographic data that there was no statistically significant difference of age, parity, gestational age between the study and the control group but there was statistically significant difference of gravidity between the two groups.

As regard the vital data; there was statistically significant difference of blood pressure between mild and severe preeclampsia groups.

As regard the investigations; there was statistically significant difference of proteinuria, fatal hemoglobin and uterine Doppler ultrasound between mild and severe preeclampsia groups.

Conclusion: Fetal hemoglobin level in maternal blood is an important, simple, cheap and available biomarker for preeclampsia. it can be used late in pregnancy for diagnosis of preeclampsia and for determining the severity of pre-eclampsia.

Key Words: Preeclampsia-Fetal hemoglobin-Eclampsia - HELLP Syndrome oxidative stress - Placenta - Vascular endothelial growth factor - Alpha 1 microglobulin.

Correspondence to: Dr. Fatma A. Abdalla Ali, E-Mail: fatmaabdelsalam89f@gmail.com

\section{Introduction}

PREECLAMPSIA is a disorder of widespread vascular endothelial malfunction and vasospasm that occurs after 20 weeks of gestation and affecting $3-7 \%$ of pregnant women. Preeclampsia is one of the leading causes of maternal mortality and morbidity especially in the developing countries [1,2]

Preeclampsia is diagnosed when pregnant women develop hypertension (BP $\geq 140 / 90$ at two separate times) and proteinuria (presence of at least $300 \mathrm{mg}$ of protein in a 24-hour urine collection or a urine dipstick reading of $>_{-}+1$ ) with or without pathological edema [3,4]

\section{Preeclampsia may be complicated by:}

HELLP syndrome, eclampsia, hemorrhagic or ischemic stroke, liver damage and dysfunction, acute kidney injury, acute respiratory distress syndrome [5,6,7].

Preeclampsia is also associated with increased frequency of Caesarian section, preterm delivery, and placental abruption. Fetal complications include fetal growth restriction and potential fetal or perinatal death $[7,8]$.

Prevention of preeclampsia includes aspirin, calcium supplementation and blood pressure medications such as labetalol and methyldopa that may be used to improve the mother's condition before delivery [9].

Magnesium sulfate may be used to prevent eclampsia in those with severe disease. Bed rest and salt intake restriction have not been found to be useful for either treatment or prevention [10]

Currently, only symptomatic blood pressure treatment is available for preeclampsia and the 
only known cure to date is delivery of the fetus and placenta. When delivery becomes recommended depends on how severe the preeclampsia and how far along in pregnancy a person is (WHO, 2011).

The exact cause of preeclampsia remains unclear; there is a strong evidence that a major cause predisposing a susceptible woman to preeclampsia is an abnormally implanted placenta.

This abnormally implanted placenta may result in poor uterine and placental perfusion leading to a state of hypoxia and increased oxidative stress $[11,12]$

Free fetal hemoglobin (outside red blood cells) is a potential key factor in the pathogenesis of preeclampsia by aggravating oxidative stress causing damage to the placental barrier and leaking into the maternal blood stream. It causes endothelial damage and vasoconstriction $[\mathbf{1 3 , 1 4 ]}$

Leakage of cell-free fetal hemoglobin (HbF) into the maternal circulation has been documented in women with preeclampsia. This leakage of $\mathrm{HbF}$ from the placenta into the maternal circulation with increased levels of cell-free $\mathrm{HbF}$ could be documented as early as the first trimester in women who subsequently developed preeclampsia $[\mathbf{1 5 , 1 6}]$

Predictive tests such as Doppler Ultrasound of the uterine arteries to investigate signs of inadequate placental perfusion, elevations of serum uric acid and angiogenic proteins such as vascular endothelial growth factor (VEGF) and placental growth factor (PGF) [7]

Recent studies have been suggested that the presence of cell-free $\mathrm{HbF}$ in the maternal circulation is not only an important factor in the pathophysiology but also a potential and useful biomarker for prediction and diagnosis of preeclampsia [17]

\section{Patients and Methods}

A retrospective study was conducted on pregnant women diagnosed as preeclampsia and admitted at Tanta University Hospital in a duration of one year from September 2016 to September 2017. All patients were undergoing the standard procedures of the protocol.

\section{Ethics of the study:}

- An approval from the ethical committee and an informed written consent was taken from each patient after explanation of benefits and risks.
- Any unexpected risk appeared during the course of the study was cleared to the patients and the ethical committee on time and the proper measures were taken to overcome these risks.

- All patients' data were confidential with secret codes and were used for the current study only.

\section{Study population:}

Case control study was carried out in a duration of one year. It was conducted upon total number 60 pregnant women in Tanta University Hospitals classified into:

- Group I (Study group): This group includes 40 pregnant women diagnosed as Preeclampsia at gestational age (28-40 weeks) and subdivided into:

\section{a- Group (IA):}

This group included 20 pregnant women diagnosed as mild Preeclampsia.

\section{b- Group (IB):}

This group included 20 pregnant women diagnosed as severe preeclampsia.

- Group II (Control group): This group included 20 healthy pregnant women with uncomplicated pregnancy.

Inclusion criteria: Primigravida, multigravida, age (18-35 years old), gestational age (28-40 weeks), BP > 140/90 and Proteinuaria >_+1.

Exclusion criteria: Chronic hypertension, gestational hypertension, epilepsy, renal diseases, liver diseases, hemolytic uremic syndrome. thrombotic thrombocytopenic purpura, gall bladder disease, pancreatic disease, diabetes mellitus, twins and old primigravida >35 years old.

\section{All patients underwent the following:}

Full history including: Maternal age, parity, number of gestations, gestational age, medical history (diabetes, hypertension, cardiac, chest diseases or epilepsy), special habits and drug history.

Full clinical examination: Vital data (blood pressure, heart rate, temperature, respiratory rate, random blood sugar), neurological, cardiovascular, chest, abdominal and extremities examination.

Laboratory investigations: Complete blood count, liver function test, serum creatinine, urine analysis, random blood sugar and fetal hemoglobin. 
Radiological investigation: Uterine Doppler Ultrasound.

\section{Blood sampling:}

About $5 \mathrm{ml}$ venous blood sample was taken from each patient. $2 \mathrm{ml}$ blood was put into vacutainer EDTA tube for complete blood picture. The remaining $3 \mathrm{ml}$ was put in vacutainer tube without additives for estimation of liver function tests, renal function tests, fetal hemoglobin and random blood sugar.

Estimation of serum fetal hemoglobin in maternal blood by Enzyme Linked Immunosorbent Assay (ELISA) supplied by Shanghai Sunred Biological Technology Co., Ltd.

\section{Principles:}

Fetal hemoglobin in samples were added to monoclonal antibody Enzyme well; which is precoated with Human fetal hemoglobin monoclonal antibody and then incubated.

Fetal hemoglobin antibodies labeled with biotin, and Combined with Streptavidin-HRP were added to form immune complex; then carry out incubation and washing again to remove the uncombined enzyme.

Chromogen Solution A, B was added so, the color of the liquid changes into the blue, and at the effect of acid, the color finally becomes yellow.
The chroma of color and the concentration of the Human Substance fetal hemoglobin of sample were positively correlated.

Reference values: Serum level: $<0.5 \mathrm{ug} / \mathrm{ml}$.

\section{Statistical analysis:}

In this study, data were organized and tabulated. SPSS version 23 (Statistical Package for Social Studies) created by IBM, Illinois, Chicago, USA was used to statistically analyze the collected data. The level of significant was adopted at $p<0.05$.

\section{Results}

The results were summarized, tabulated and statistically analyzed in the following tables and figures. Sociodemographic data are presented in Table (1).

The study revealed as regard socio demographic data that there was no statistically significant difference of age, parity, gestational age between the study and the control group but there was statistically significant difference of gravidity between the two groups.

About $10 \%$ of group IA while $25 \%$ of group IB showed signs of inadequate placental perfusion.

Table (1): Comparison of baseline criteria between the study and the control groups.

\begin{tabular}{lllll}
\hline Baseline criteria & Group IA & Group IB & Group II & $p$-value \\
\hline Age (years) & $29.2 \pm 3.607$ & $30.1 \pm 3.410$ & $27.8 \pm 2.913$ & 0.106 \\
Gestational age (weeks) & $33.8 \pm 3.679$ & $33.5 \pm 3.426$ & $31.7 \pm 3.840$ & 0.159 \\
Gravidity (times) & $2.3 \pm 1.324$ & $4.7 \pm 2.477$ & $2.3 \pm 1.218$ & $<0.001$ \\
Parity (times) & $1.1 \pm 1.252$ & $1.95 \pm 1.432$ & $1.2 \pm 1.240$ & 0.090 \\
Fetal hemoglobin & $1.5 \pm 0.530$ & $2.5 \pm 0.705$ & $0.7 \pm 0.184$ & $<0.001$ \\
\hline
\end{tabular}

Table (2): Correlation between HBF level and other measures.

\begin{tabular}{lcc}
\hline & \multicolumn{2}{c}{ Fetal hemoglobin (HBF) } \\
\cline { 2 - 3 } & Pearson correlation & $p$-value \\
\hline Gravidity & 0.301 & $0.019^{*}$ \\
SBP & 0.772 & $<0.001^{*}$ \\
DBP & 0.726 & $<0.001^{*}$ \\
Proteinuria & 0.726 & $<0.001^{*}$ \\
\hline
\end{tabular}

Table (3): Sensitivity and accuracy of fetal hemoglobin in diagnosis of preeclampsia.

\begin{tabular}{lccccc}
\hline \multirow{2}{*}{$\begin{array}{l}\text { Cut } \\
\text { off }\end{array}$} & \multicolumn{5}{c}{ Accuracy of fetal hemoglobin } \\
\cline { 2 - 6 } & Sensitivity & Specificity & PPV & NPV & Accuracy \\
\hline 0.8 & $82.5 \%$ & $85 \%$ & $91.67 \%$ & $70.83 \%$ & $83.33 \%$ \\
\hline
\end{tabular}

* Denotes Statistical Significance. 


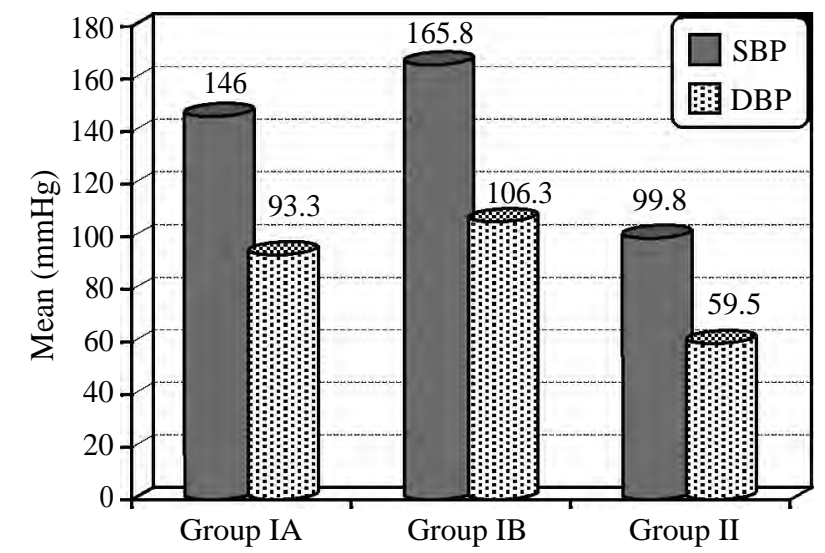

Fig. (1): Comparison of SBP and DBP between the study and the control group.

SBP: Systolic blood pressure. DBP: Diastolic blood pressure.

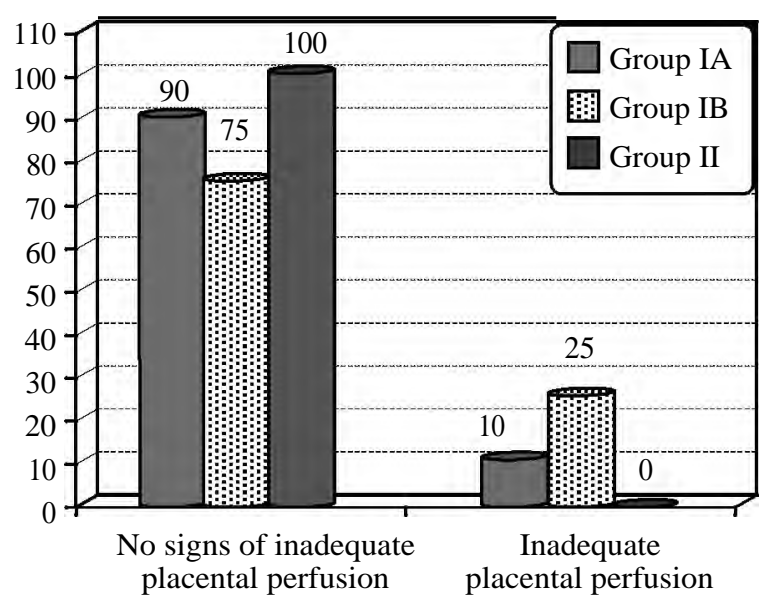

Fig. (2): Comparison of Doppler US finding between the PE and the control groups.

\section{Discussion}

Preeclampsia (PE) is one of the most serious complication in pregnancy. At this time, PE still lacks early means of diagnosis and markers that determine the severity of the condition.

Recent studies reported that extracellular fetal hemoglobin $(\mathrm{HbF})$ in maternal blood is involved in the pathogenesis of preeclampsia and its concentration in the maternal serum can be used as early predictive biochemical marker for preeclampsia.

This study was performed to correlate between the level of fetal hemoglobin in the maternal serum and the severity of preeclampsia.

In the present study, the mean gestational age at sampling in the preeclampsia group (group I) was 33.6 weeks.

In Anderson et al. [18] and Anderson U et al. [14] studies, the mean gestational age at sampling for the Preeclampsia group was 13.7 and 14.1 weeks.

This variation in gestational age can be explained by the difference in the aim of each study. In our study, cases were selected at late pregnancy till the manifestations of severe preeclampsia become well established so, we can correlate the level of fetal hemoglobin between mild and severe cases.

While in the other studies, cases were selected at early pregnancy as this studies were performed to prove that fetal hemoglobin is an early predictive biochemical marker for preeclampsia during the first trimester.

This study found that women with preeclampsia (group I) were older than patients in control group (group II) with a mean age was 29.7 and 27.8 respectively.

A study by Gram et al. [19] was in agreement with our study and found that the mean maternal age was 31 years in preeclampsia group.

Another study by Olsson et al. [20] agreed with our results in which the mean maternal age was 30 years in the Preeclampsia group.

Our study found that most preeclampsia patients showed a history of multiple pregnancy. The mean number of gravidity was 3.5 in preeclampsia group (2.3 and 4.7 in mild and severe preeclampsia respectively).

These findings agreed with Anderson et al. [18] who evaluated the maternal serum levels of $\mathrm{HbF}$ as predictive biomarkers for preeclampsia. They found that the mean number of gravidity was 2.7 in preeclampsia patients.

High blood pressure is important for diagnosis of preeclampsia. Severe preeclampsia is associated with higher blood pressure. The mean systolic blood pressure was $155.9 \mathrm{mmHg}$ in preeclampsia group $(146 \mathrm{mmHg}$ and $165.8 \mathrm{mmHg}$ in mild and severe preeclampsia respectively).

The mean diastolic blood pressure was 99.3 $\mathrm{mmHg}$ in preeclampsia group $(93.3 \mathrm{mmHg}$ and $106.3 \mathrm{mmHg}$ in mild and severe preeclampsia respectively).

Results of Gram et al. [19] study that investigated the levels of cell-free fetal hemoglobin in plasma of preeclampsia women were similar to our results. 
They found that the mean systolic blood pressure was $161 \mathrm{mmHg}$ and the mean diastolic blood pressure was $101 \mathrm{mmHg}$ in preeclampsia group.

Also, Olsson et al. [20] study that analyzed fetal hemoglobin in women diagnosed as preeclampsia was in agreement with our results and found that the mean systolic blood pressure was $149 \mathrm{mmHg}$ and the mean diastolic blood pressure was $103 \mathrm{mmHg}$ in preeclampsia group.

\section{Fetal hemoglobin level in the serum of maternal blood:}

In the present study, fetal hemoglobin level was higher in preeclampsia patients. Severe preeclampsia cases showed higher level of fetal hemoglobin when compared to mild preeclampsia cases. The mean value was $0.6 \gamma \mathrm{g} / \mathrm{ml}, 1.7 \gamma \mathrm{g} / \mathrm{ml}$ and $2.7 \gamma \mathrm{g} /$ $\mathrm{ml}$ in the control, mild PE and severe PE groups with sensitivity $82.5 \%$ and specificity $85 \%$.

Fetal hemoglobin level in the serum of maternal blood increased three-folds in patients with mild preeclampsia and more than four-folds in patients with severe preeclampsia. So, HBF in our study was well correlated with the severity of PE.

Our study was in line with Anderson et al. [18] who found that the mean value of fetal hemoglobin was $5.6 \gamma \mathrm{g} / \mathrm{ml}$ in the control group and $10.1 \mathrm{\gamma g} / \mathrm{ml}$ in the preeclampsia group (two-fold increase) with sensitivity $65 \%$. They also found that HBF level in early pregnancy in women who subsequently developed preeclampsia was elevated so, it can be used in prediction and early diagnosis of preeclampsia.

A study by Gram et al. [19] reported results similar to our findings with the mean fetal hemoglobin $3.85 \mathrm{ng} / \mathrm{ml}$ and $14.6 \mathrm{ng} / \mathrm{ml}$ in control group and preeclampsia. There was a four-fold increase in preeclampsia group compared with the control group.

Results found by Annalisa et al. [21] was in agreement with this study. The concentration of fetal hemoglobin in early pregnancy was significantly elevated in women who subsequently developed preeclampsia with sensitivity $69 \%$.

In agreement with the present study, Anderson et al. [22] found that sensitivity of HBF in diagnosis of preeclampsia was $70 \%$. They also reported that fetal hemoglobin plays a central role in the pathophysiology of preeclampsia.

A study by Anderson et al. [14] reported results similar to our findings. The mean value of fetal hemoglobin level was 1.38 and $0.45 \gamma \mathrm{g} / \mathrm{ml}$ in preeclampsia group and control group respectively with three-fold increase in HBF in preeclampsia group compared with control group and sensitivity $78 \%$. They concluded that the serum concentration of fetal hemoglobin has the potential of being used as first trimester biochemical marker for the subsequent development of preeclampsia.

Olsson et al. [20] reported that the fetal hemoglobin level in preeclampsia group (mean value $1.09 \gamma \mathrm{g} / \mathrm{ml}$ ) increased nine-folds compared with control group (mean value $0.126 \gamma \mathrm{g} / \mathrm{ml}$ ).

These variations in sensitivity may be due to small size of sample in our study. Also the gestational age at sampling was above 28 weeks (preeclampsia signs become well established and fetal hemoglobin level increased). While in the other studies, gestational age at sampling was early in the first trimester.

In conclusion, fetal hemoglobin concentration in the maternal serum is considered an important biomarker in preeclampsia for the following characteristics:

- HbF Plays a central role in the pathogenesis of preeclampsia.

- It can be used for early prediction of the disease in early pregnancy as it appears early or before the clinical manifestations.

- $\mathrm{HbF}$ is a simple test and is available to be measured in the maternal blood.

- It shows a high sensitivity (82.5\%) and specificity $(85 \%)$.

- It correlates with the severity of the condition in late pregnancy.

- Be expressed at very low levels in normal pregnancy.

\section{Limitation of the study:}

- The limited number of our patients in both groups.

- Women in this study were selected at gestational age older than other studies previously reported.

These limitations could have an impact on our findings.

\section{Conclusion:}

In conclusion, fetal hemoglobin level in the serum of maternal blood is an important, simple, cheap and available biomarker for pre-eclampsia. 
It can be used late in pregnancy for diagnosis of preeclampsia and for determining the severity of pre-eclampsia.

\section{Recommendation:}

Serum fetal hemoglobin is a good prognostic marker for preeclampsia that present in higher level in severe cases than mild cases so, we recommend using it in follow-up of preeclampsia.

\section{References}

1- MACKAY, ANDREA P., CYNTHIA J., et al.: "Pregnancyrelated mortality from preeclampsia and eclampsia." Obstetrics \& Gynecology, 533-538, 2001.

2- BERG, CYNTHIA, CALLAGHAN W., et al.: "Overview of maternal morbidity during hospitalization for labor and delivery in the United States: 1993-1997 and 20012005". Obstetrics \& Gynecology, 1075-1081, 2009.

3- REDMAN C.: "Hypertension in pregnancy: The NICE guidelines". Heart, 97.23.: 1967-1969, 2011.

4- LONGO and DAN L.: "Harrison's principles of internal medicine". New York: McGraw-HillI S., 55-61, 2012.

5- SCHROEDER and BARRETT M.: "ACOG practice bulletin on diagnosing and managing preeclampsia and eclampsia". American College of Obstetricians and Gynecologists. American Family Physician, 330, 2002.

6- ARULKUMARAN N. and LIGHTSTONE L.: "Severe pre-eclampsia and hypertensive crises". Best Practice \& Research Clinical Obstetrics \& Gynaecology, 877-884, 2013.

7- MUSTAFA S., GUPTA L., et al.: "A Comprehensive Review of Hypertension in Pregnancy". Journal of Pregnancy, 1-19, 2012.

8- SHMUEL I., HAMUTAL M., RON G., et al.: "Economic assessment of screening for pre-eclampsia". Prenatal diagnosis, 29-38, 2012.

9- HENDERSON A., JILLIAN T., THOMPSON J., et al.: "Low-dose aspirin for prevention of morbidity and mortality from preeclampsia: A systematic evidence review for the US Preventive Services Task Force". Annals of Internal Medicine, 695-703, 2014.

10- AL-JAMEIL A., NOURA F.K., et al.: "A brief overview of preeclampsia". Journal of Clinical Medicine Research, $1-7,2013$.

11- STEEGERS E.A.P., PIJNENBORG R., et al.: "Preeclampsia". The Lancet, 631-644, 2010.
12- CENTLOW M., CARNINCI P., et al.: "Placental expression profiling in preeclampsia: Local overproduction of hemoglobin may drive pathological changes". Fertility and Sterility, 1834-1843, 2008.

13-MAY K., OLSSON M., CENTLOW M., et al.: "Perfusion of human placenta with hemoglobin introduces preeclampsia-like injuries that are prevented by a 1 microglobulin". Placenta, 323-332, 2011.

14-ANDERSON U.D., OLSSON M., et al.: "Fetal hemoglobin and a 1-microglobulin as first-and early second-trimester predictive biomarkers for preeclampsia". American Journal of Obstetrics and Gynecology, 520, 2011.

15- ANDERSON U.D., GRAM M., et al.: "Fetal hemoglobin, $\alpha 1$-microglobulin and hemopexin are specific predictive first and second trimester biomarkers of preeclampsia". Placenta, 58, 2015.

16- HANSSON S.R., MAGNUS G., et al.: "Fetal hemoglobin in preeclampsia: A new causative factor, a tool for prediction/diagnosis and a potential target for therapy". Current Opinion in Obstetrics and Gynecology, 448-455, 2013.

17- HANSSON S.R., LENA E., et al.: "Oxidative stress in preeclampsia and the role of free fetal hemoglobin". Frontiers Inphysiology, 516, 2015.

18- ULRIK A., MAGNUS G., JONAS R., et al.: "Fetal hemoglobin, a1-microglobulin and hemopexin are potentialpredictive first trimester biomarkers for preeclampsia". Pregnancy Hypertension: An International Journal of Women's Cardiovascular Health, 2016.

19- MAGNUS G., ULRIK A., MARIA E., et al.: "The Human Endogenous Protection System against Cell-Free Hemoglobin and Heme Is Overwhelmed in Preeclampsia and Provides Potential Biomarkers and Clinical Indicators". Obstetrics and Gynecology, Lund, Sweden, 2015.

20- OLSSON, MAGNUS, CENTLOW M., et al.: "Increased levels of cell-free hemoglobin, oxidation markers, and the antioxidativeheme scavenger a 1-microglobulin in preeclampsia". Free Radical Biology and Medicine, 284291,2010

21- ANNALISA I., MADDALENA S., MASSIMO C., et al.: "Predictive biomarkers of pre-eclampsia and effectiveness of preventative interventions for the disease". Genomic Unit for the Diagnosis of Human Pathologies, Milan, Italy.

22- ANDERSON U., OLSSON M., KRISTENSEN K., et al.: "Biochemical Markers to Predict Preeclampsia". Placenta, 2012. 


\section{دور الهيموجلوبين الجنينى في دم دم الأم

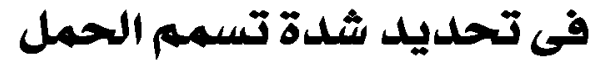

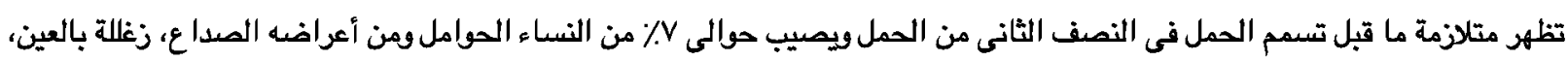

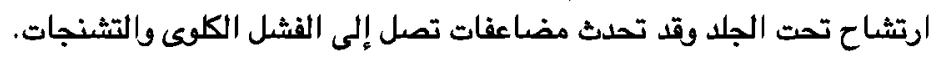

فى الأونة الأخيرة تبين أن الهيموجلوبين الجنينى فى دم الأم هو عامل رئيسى محتمل فى التسبب في المرض نتيجة لتفاقم الأكسدة مما

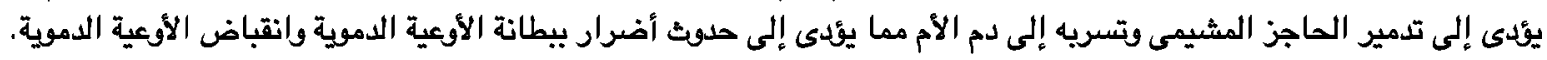

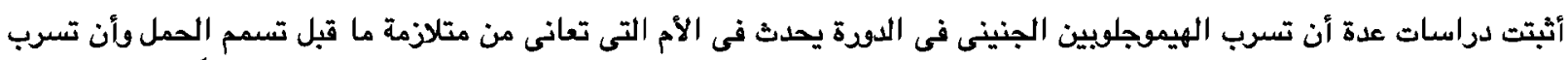

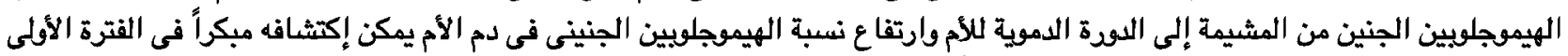

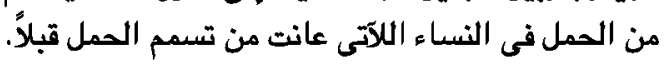

يهدف البحث إلى دراسة العلاقة بين الهيموجلوبين الجنينى فى لدم الأم التى تعانى من تسمم الحمل وثدة المرض فى مستشفيات طنطا الجامعية.

تم أجراء الدراسة على مرضى يعانين من تسمم الحمل فى مستشفيات جامعة طنطا على مدار عام وقد اشتملت على عدد ستين ( ( ) من النساء الحومل.

أظلهرت الدراسة أنه لا يوجد أختلافاً إحصائياً كيراً بين مجموعات الدراسة بالنسبة لـ سن الأم وبن الجنين وعدد هرات الولادة غير أن هناك فارق إحصائى فى عدد مرات الحمل.

أُن هناك فارقاً إحصائياً كبيراً بين مجموتى الدراسة بالنسبة لضفط الدم ونسبة الزلال بالبول والعونار الرحمى ومعدل الهيموجلوبين الجنينى. وأثتبتث الدراسة أن معدل الهيموجلوبين الجنينى يزداد في حالات تسمم الحمل الشديدة عن الحالات المعتلة. 